\title{
Chapter 15 \\ Commemorating Historically Significant Gay Places Across the United States
}

\author{
Camden Miller and Alex Bitterman
}

\begin{abstract}
The stories of gay spaces across the United States are largely unrecorded, undocumented, and are not centrally collected or archived beyond informal reports and oral histories. Evidence demonstrates that the preservation of historic sites allows for future generations to benefit from intangibles related to community and identity. However, the LGBTQ+ community has been unable to gain benefits that place-based, historic sites can provide, due to an inability to commemorate spaces that have shaped LGBTQ+ history in significant ways. This chapter explores the disparities between the preservation and commemoration of significant LGBTQ+ spaces and the amount of funding distributed to these sites. As of 2016, LGBTQ+ sites comprised only 0.08 percent of the 2,500 U.S. National Historic Landmarks and 0.005 percent of the more than 90,000 places listed in the National Register of Historic Places. This representation is well short of the share of American adults that identify as LGBTQ+, which in 2017 was approximately five percent of the United States population. In 2010 the Administration of President Barack Obama launched the LGBTQ Heritage Initiative under the National Historic Landmarks Program. This effort underscored a broader commitment to include historically underrepresented groups, including LGBTQ+ individuals. As a result, LGBTQ+ communities became eligible to receive funding for projects through the Underrepresented Community Grant Program. An analysis of the distribution of Underrepresented Community Grant Program funds revealed that the LGBTQ+ community receives considerably less funding compared to other underrepresented communities. The findings from this study suggest that there is still a significant amount of work that remains to be done to integrate LGBTQ+ histories into historic preservation programs that exist at various levels of programming (local, state, and federal).
\end{abstract}

Keywords Historic preservation - Place-based identity - Underrepresented Community Grant · National Park Service $\cdot$ LGBTQ+ heritage

C. Miller

Urban and Regional Planning, University at Buffalo, Buffalo, NY, USA

e-mail: camdenmi@buffalo.edu

A. Bitterman ( $\square)$

State University of New York, Alfred State, Alfred, NY, USA

e-mail: bittera@alfredstate.edu

(C) The Author(s) 2021

A. Bitterman and D. B. Hess (eds.), The Life and Afterlife of Gay Neighborhoods,

The Urban Book Series, https://doi.org/10.1007/978-3-030-66073-4_15 


\subsection{Generations of Gay History}

Gay spaces across the United States are steeped in important and ephemeral history. However, the stories of these spaces - and the people that lived the struggle to gain LGBTQ+ rights - are largely unrecorded, undocumented, and are not centrally collected or archived beyond Wikipedia entries and oral histories. Many gay places and gay neighborhoods have no formal means of recognition or historic protection such as those that are available to other classifications of landmarks from state or federal agencies. The pioneering generation that gave rise to the LGBTQ+ rights movement is aging and the time to capture the unprecedented-and largely undocumented-history of their efforts and struggle is endangered. As this generation of LGBTQ+ elders ages and eventually passes on, the detailed histories, documents, and stories of this courageous generation will be lost and will become unavailable for future scholarly analysis or review (Bitterman and Hess 2016; Bitterman and Hess 2021). With this loss, aspects of the history of the struggle for LGBTQ+ rights in the United States stands a chance of becoming lost, forever, in the shuffle of history. It is vital that all groups are equally represented in their ability to memorialize and preserve their own histories and culture as part of a broader cultural context. While "people survive the loss of places that support their identity," (Mayes 2018) these places take on a greater meaning. The phrase "many times, these places survive in memory," (Mayes 2018) suggests a type of "afterglow" which "denotes a post-place as an imaginary-symbolic effect that percolates through deterritorialized networks" (Coffin 2021). In this way, "the continued presence of old places helps us know who we are and who we may become in the future" (Mayes 2018).

Late in the Obama administration (2014-2017) a United States Federal effort, through the National Park Service as part of the U.S. Department of the Interiorendeavored to identify, commemorate, and landmark sites that were significant to the LGBTQ+ struggle for civil rights across the United States-began to see some unrecognized work start to gain traction (U.S. Department of the Interior 2014a). This effort built upon an emerging heritage effort that began in the 1960s through legislation focusing on the preservation of significant sites in the built environment of special historic value. However, in the years following the Obama administration stewardship, the Federal effort to identify, landmark, and protect LGBTQ+ heritage sites has been de-prioritized at the Federal level. As discussed later in this chapter, certain U.S. states, such as New York, have stepped into fill the post-Obama Federal void by identifying, commemorating, and protecting LGBTQ+ heritage sites within state boundaries.

Efforts to commemorate and landmark significant LGBTQ+ sites become part of the history and ongoing struggle for LGBTQ+ civil rights. These civil rights have historically been explicitly denied by both government and society (National Park Service 2019b; Garretson 2018). LGBTQ+ spaces, though important to LGBTQ+ people, belong to everyone and are part of a diverse and rich history, extending beyond the specific history of LGBTQ+ individuals. Evidence demonstrates that the preservation of historic sites allows for future generations to benefit from intangibles 
related to community and identity (Mayes 2018). Historic sites allow for people to define who they are, to identify a sense of self, and to feel as though they belong to a welcoming community or a distinct effort or movement (Wood 1999; Mayes 2018; Zinn 2014).

The preservation of historically significant sites extends beyond maintaining old buildings or installing commemorative plaques at important sites. Historically significant LGBTQ+ sites have the ability to impact generations of people, their identity, and their lives by providing LGBTQ+ individuals and others with a source of inspiration and motivation (Bitterman and Hess 2021; Hess and Bitterman 2021). However, the LGBTQ+ community has been unable to gain the intangible benefits that placebased, historic sites can provide, due to an inability of the LGBTQ+ community to memorialize and commemorate spaces that have been significant to shaping its history. In this way, the preservation of historic LGBTQ+ sites is more significant than just the physicality of place. The importance of preserving significant LGBTQ+ sites and the benefits of place-based history are explained by LaFrank (2020), the New York State Parks \& Sites Historian for the New York State Historic Preservation Office:

This is helping real people to appreciate not only their history, but to appreciate and love themselves, to accept themselves, to find community with other people like themselves, and just to be themselves. In other words, to erase all of the old hiding and shame, and I don't want to go so far as to say it, but I think it saved people's lives. It seems to me that this goes way beyond preservation. Preserving people and preserving communities is just not the same as putting a plaque on an old house, not that I'm against that, I've hung my share of plaques. But it provides a more expansive view of history that benefits all of us. And so, the idea of expanding history to include everybody's story and everybody's history. It helps people to validate their own lives, appreciate their own lives, and appreciate each other. (LaFrank 2020)

In thinking about moving forward, it is necessary to understand the importance for everyone, regardless of how they identify, to be seen.

The effort to preserve and commemorate sites significant to LGBTQ+ history has been ongoing for nearly fifty years. In 1995, urban historian and architect Dolores Hayden hoped for an expansive social history of place that included ethnicity and gender, and that would be transformative, "redefining the mainstream experience, and making visible some of its forgotten parts" (Hayden 1997: xi-xii). In increasing the use of Federal funding to support historic preservation, Hayden finds a mandate for a more expansive history by referring to Gans (Gans 1975: 33) "private citizens are of course entitled to save their own past, but when preservation becomes a public act, supported with public funds, it must attend to everyone's past." This includes the past of LGBTQ+ people, whose lives and experiences have in some cases, been actively erased (National Park Service 2019b: 02-12-13). Hayden and Gans argue that if preservation is a public act, supported by public funding, then preservation should be attentive towards everyone's past. However, if this is indeed the case, then why does funding seem to be limited and only minimally allocated to LGBTQ+ sites, yet other types of heritage sites receive more funding for nominations to be written and sites to be listed on the National Register of Historic Places or as a National Historic 
Landmark? We argue that the commemoration of historically significant LGBTQ+ sites encompasses a degree of importance beyond simply preserving history through the stories of the sites themselves, but that preservation and commemoration becomes a way to recognize people through the process of celebrating place. However, when that celebration and commemoration of those sites remain untold or systemically silenced, the history does not remain unknown, but rather acts as a method of social exclusion and oppression.

\subsubsection{Violence and Commemoration}

The United States is home to more than 1,000 battlefields from the French \& Indian War, the War of 1812, The American Revolution, and the American Civil War (Civil War Sites Advisory Commission 1993; Gossett and Mitchell 2007). ${ }^{1}$ Many battlefields commemorate the violent evolution of the fight for equality, recognition, and freedom of every American citizen. The preservation of these battlefields is maintained by various government agencies across the United States.

Violence and conflict similarly punctuate the LGBTQ+ struggle for recognition and equality (Hanhardt 2013). Sadly, many of the sites that could and arguably should be commemorated in the struggle for LGBTQ+ rights have dark or violent histories. These places are the battlefields upon which struggles for civil rights were fought. The suffering of many valiant LGBTQ+ individuals made possible the freedoms and legal protections enjoyed today. None of these sites are presently commemorated or supported by government agencies, except for perhaps one of the most known, The Stonewall Inn in New York City, which was the site of groundbreaking riots during the late 1960s that spilled out into the streets (Duberman 2019) and spurred a helped initiate significant gay rights movements during a period of sexual liberation (Carter et al. 1999). ${ }^{2}$

Other sites of violence towards LGBTQ+ individuals include:

- The UpStairs Lounge, a gay bar located in the French Quarter of New Orleans, Louisiana, was site to one of the most horrific arson attacks on June 24, 1973, resulting in the deaths of 32 people (University of New Orleans History Department 2012).

\footnotetext{
${ }^{1}$ Sites that are associated with wars fought on American soil have been identified, surveyed, and assessed through the American Battlefield Preservation Program (ABPP) established by the Secretary of the Interior in 1991. The Civil War Sites Advisory Commission, which was established by Congress in 1990, has identified 384 principal Civil War battlefields (Civil War Sites Advisory Commission 1993). The National Park Service has identified and documented 677 significant sites associated with the War of 1812 and the Revolutionary War (Gossett and Mitchell 2007).

${ }^{2}$ One of the requirements for sites to be listed on the National Register of Historic Places is the "50-year rule." This standard demonstrates chronological boundaries that have been constructed by the United States Secretary of the Interior to filter out newer sites that have not reached "historical significance" (Sprinkle Jr. 2007).
} 
- A desolate site on Snowy View Road in Laramie, Wyoming where 21-year-old Matthew Shepard was the victim of one of the most notorious U.S. hate crimes centered around homophobia. Shepard was viciously beaten, tortured, and left to die by convicted murderers Aaron McKinney and Russell Henderson, who were aided and enabled by Chasity Vera Pasley and Kristen Leann Price, all of whom were in their early 20s (Sheerin 2018).

- And more recently, the Pulse Nightclub in Orlando which was the location of the second-worst mass shooting by a single gunman in United States history on June 12,2016 , resulted in the deaths of 49 people and the injury of 53 others (Beckett 2016).

Violence toward LGBTQ+ people has occurred in various places. Many of these sites remain unidentified and potentially unknown for those who were too young, not born, or unaware of events as they happened. Immediately following tragic events, the public often demonstrates support by setting up makeshift of temporary memorials that sometimes persist for years; however, the effort to have these sites commemorated and preserved - officially — especially at a state and national level has been challenging. This effort is important in order to remember the lives-and the individuals - that were lost. Landmarking and commemorating these sites ensures that the memory of those who lost their lives in the battle for LGBTQ+ rights are not forgotten. While meaning and importance of the sites endures for generations to come, the remembrance of these tragedies helps to avoid similar acts of violence in the future. However, commemorating sites of LGBTQ+ violence and struggle remains a challenge, as the United States government spends significantly more resources to commemorate and maintain battlefields than LGBTQ+ sites, which comparatively receive precious little funding or support.

\subsection{Significant LGBTQ+ Sites}

The commemoration of LBGTQ + sites is an important component of the broader American historical narrative, and is vital for the LGBTQ+ community to identify a significant role in its shared history as well as to educate others about the struggle for LGBTQ+ rights and freedoms. A statement from the co-founders of the NYC LGBT Historic Sites Project highlights the importance of place-based identity and the preservation of physical sites associated with LGBTQ+ history:

\footnotetext{
We're interested in tangible heritage and what that means and the interpretation of it. But the intangible benefits for people are profound. For instance, a kid coming out or who is afraid to go to a Pride March can read about these places in the privacy of their own home, on the computer or on a mobile device. This information gives access to people that otherwise would not be able, for various reasons, to go and see these sites, or to explore their own histories. If I was that kid, it would have helped knowing that there is this rich history. It's not just that Stonewall was a riot and there was a gay movement that resulted. You are able to look at New York in a different way and really understand your connection to it emotionally and historically. That is profound. (Dolkart and Lustbader 2020)
} 
Elsewhere in this book, scholars explain how gay places matter (Ghaziani 2021, Hess and Bitterman 2021), and we argue in this chapter that historically significant gay places also matter. Physical historic sites encourage place-based and in situ recognition, tourism, and commemoration by allowing individuals to find deeper connections and feel a sense of belonging and identity that they might not otherwise experience. This is especially the case with minority groups, including sexual minorities under the LGBTQ+ umbrella. When minority groups are able to feel connected to a physical space, these sites then have the potential to become places of community, acceptance, and belonging.

The cultural significance of LGBTQ+ sites varies. Some LGBTQ+ historic sites are buildings or locations, such as the Stonewall Inn. In other instances, the sites are slightly larger and encompass neighborhoods or parts of neighborhoods with a proximity to or concentration of historically significant LGBTQ+ sites, such as Greenwich Village in New York City, which surrounds Christopher Street. Occasionally, the site is an entire historically significant neighborhood, like the Castro district in San Francisco. Each of these types of site offers a unique degree of importance to the broader LGBTQ+ historical narrative and intersects a still larger contextual American historical narrative. For example, lessons learned about sexual health safety from gay neighborhoods during the HIV/AIDS pandemic in the 1980s spread quickly across gay neighborhoods throughout the United States and then more slowly into mainstream American society (Bitterman and Hess 2021; Hess and Bitterman 2021). This incubation and transference is important for remembrance and commemoration, not only for LGBTQ+ individuals, but for a broader and inclusive cultural heritage and public health history.

As noted, many historically significant LGBTQ+ sites are located in or near gay neighborhoods. A sense of place and pride in place becomes more significant, especially as gay neighborhoods experience "de-gaying" due to gentrification and demographic change (Bitterman and Hess 2021; Hess 2019, Spring 2021). Supporting the commemoration of places steeped in LGBTQ+ history-private residences, bars, cafes, or parks - enables these places to become places of community celebration and focal points for gay neighborhoods to strengthen or potentially for new gay neighborhoods to emerge (Kinahan and Ruther 2020).

\subsubsection{LGBTQ+Heritage Initiative}

The United States National Historic Preservation Act of 1966 established the preservation of historic and archaeological sites within the United States, resulting in the creation of various entities managed by the National Park Service: National Register of Historic Places (NRHP or NR), the National Historic Landmarks (NHL) list, and 
State Historic Preservation Offices (SHPO) (U.S. Department of the Interior 1966). ${ }^{3}$ Through these programs, the United States government commemorates various significant heritage sites that represent and reflect the diverse American population (National Park Service 2019c). However, LGBTQ+ individuals are largely underrepresented by these efforts. Place-based programs orchestrated by the U.S. National Park Service are significant to the narrative of United States history and American people and culture, but fall well short of representing all people and narratives. To ameliorate this shortfall, the LGBTQ Heritage Initiative program was enacted in 2014 by the National Park Service for a number of minority communities that are underrepresented in the National Register of Historic Places and the National Historic Landmarks listings, including: African American, American Latina/Latino, Asian American and Pacific Islander, Disabled, Indigenous People, Women, and LGBTQ+ individuals. Through this effort, the National Park Service has begun to take action to tell "the history of all Americans in all of its diversity and complexity" (National Park Service 2019d:1). At present, LGBTQ+ sites make up only 0.08 percent of the 2,500 National Historic Landmarks and 0.005 percent of the more than 90,000 places on the National Register of Historic Places as of 2016 (National Park Service 2019b). This representation is well short of the share of American adults that identify as LGBTQ+, which in 2017 was approximately 5 percent (Newport 2018).

\subsubsection{Protecting American LGBTQ+ Heritage}

In November 1999, the United States Congress enacted the National Park System New Area Study Act of 2000 which directed the U.S. Secretary of the Interior to conduct a series of special resource studies. ${ }^{4}$ The Civil Rights Framework for Identifying Significant Sites, completed in 2002 and revised in 2008, lays out a plan for studies to focus specifically on civil rights sites at a multi-state level, leading to a call for projects that would address the underrepresentation of certain groups in the National Register of Historic Places and National Historic Landmarks programs (Fig. 15.1) (National Park Service 2008, 2019b).

In 2010, the Administration of President Barack Obama launched the Lesbian, Gay, Bisexual, Transgender, and Queer (LGBTQ) Heritage Initiative under the National Historic Landmarks Program (U.S. Office of the Press Secretary 2016) and by so doing, underscored a broader commitment to include historically underrepresented groups, including LGBTQ+ individuals and communities. The four goals of the LGBTQ Heritage Initiative include (1) increasing listings in the National Register of Historic Places, (2) identifying, documenting, and nominating National

\footnotetext{
${ }^{3}$ The National Register of Historic Places recognizes historical significance at local, state, and national levels while the National Historic Landmark program acknowledges exceptional national significance (National Park Service 2019b).

${ }^{4}$ The New Area Study Act of 2000 (S. 1349) falls within Public Law 106-113, Appendix C, "National Park Service Studies Act of 1999".
} 

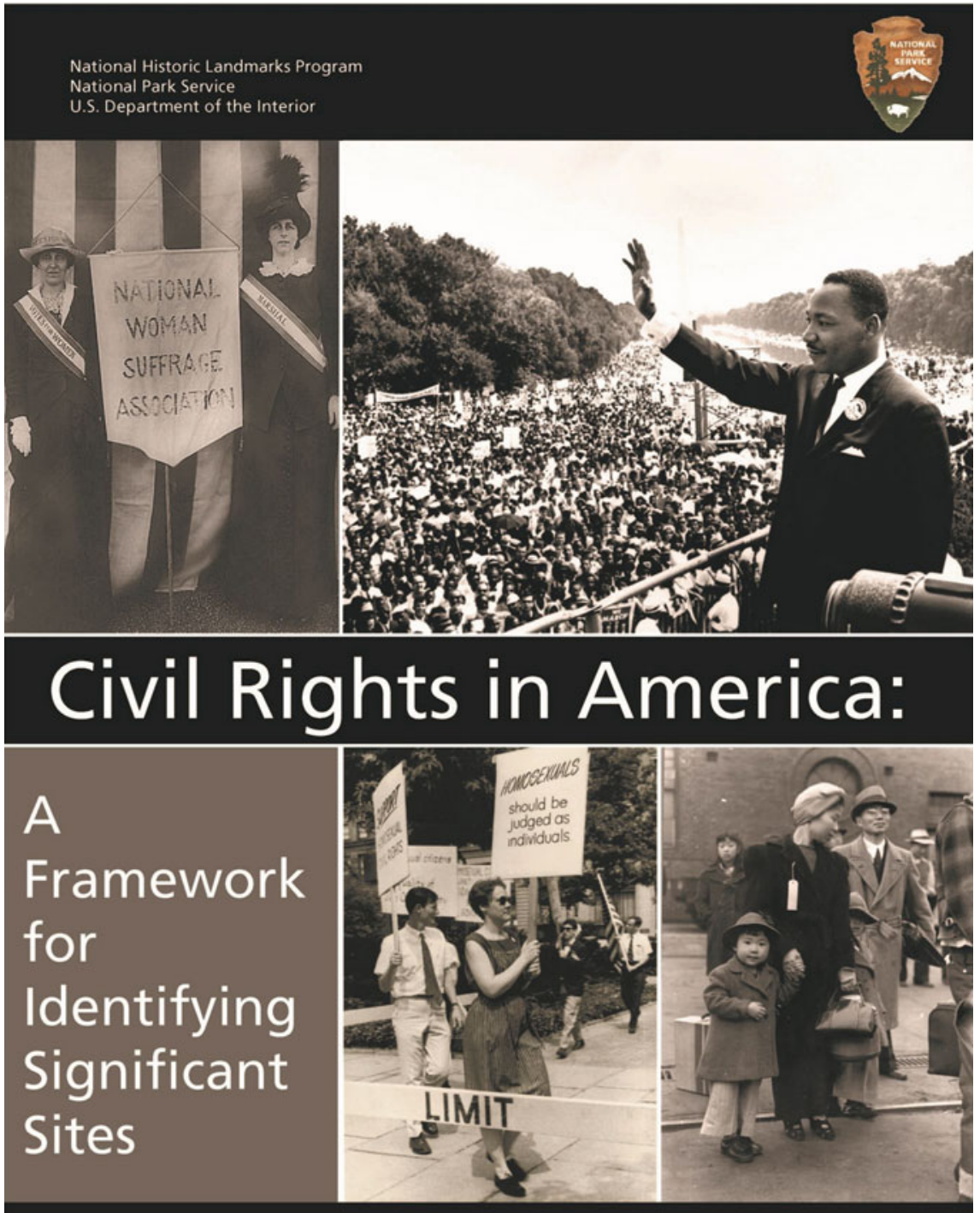

Fig. 15.1 Cover of "Civil Rights in America: A Framework for Identifying Significant Sites." Cover of the report features a number of groups which are underrepresented in NRHP and NHL programs, including Barbara Gittings and Randy Wicker in picket line outside Independence Hall, Philadelphia, PA, July 4, 1966, carrying a sign that says "Homosexuals should be judged as individuals" (Source National Park Service, 2008, public domain image) 
Historic Landmarks associated with LGBTQ+ heritage, (3) engaging the community to identify additional sites associated with LGBTQ+ history and heritage, and (4) to encourage National Park Service units to interpret associated stories (National Park Service 2019b: 02-6).

Increasing the number of listings of LGBTQ+-associated properties in the National Register of Historic Places and National Historic Landmarks facilitates preservation of the significant stories of many of these sites and properties. Not only will this initiative help to identify new sites, but this effort will also support the documentation and nomination of other LGBTQ+ significant sites. In addition, sites that may already be listed have the opportunity to "come out" as LGBTQ+ sites and have the stories of these places publicly unveiled and enriched through community recognition. This will allow for more LGBTQ+-associated histories to be revealed and shared, and by so doing, allow for more places to hold meaningful connections for all people, thereby increasing the capacity for place-based identity of LGBTQ+ individuals. Additionally, the LGBTQ Heritage Initiative also aims to engage scholars and LGBTQ+ community members who can work to identify possible sites associated with LGBTQ+ heritage and history. This effort will lead to the nomination of properties for various levels of recognition and preservation at the local, state, and national level.

Community involvement engages not only professional historic preservationists and academics, but also those involved with making history at these sites, as well as armchair historians, champions, and activists in uncovering the untold or lesserknown stories of the LGBTQ-significance of these sites. This inclusive approach allows citizens to shape who gets to tell the story and history of a community or place. Ultimately the initiative attempts to encourage the National Park Service and all affiliated agencies at the local, state, and national level to begin to interpret LGBTQ+ stories that are associated with the sites that already are maintained, preserved, and protected. Even if LGBTQ+ history is not yet formally documented, the groups who oversee these places are encouraged to begin to research and disseminate these stories at relevant sites using various approaches including, tours, didactic signage, pamphlets, and other educational materials.

Memorializing, commemorating, and preserving LGBTQ+ sites is not only vital to the education and celebration of the LGBTQ+ community, but also creates a physical relation to and experience in places for people to make distinct connections to history. Memorializing LGBTQ+ spaces creates tangible, visceral experiences with place-based history that can provide people with connections to an identity, a moment, and a story. LGBTQ+ historic spaces should not be considered differently than other historically significant sites, and thus should be considered on the same terms and eligible for equal funding and support. 


\subsubsection{Aim of Landmarks Dedication}

Although the original preservation act became law in 1966-44 years prior to the LGBTQ Heritage Initiative - the collective public voice of the LGBTQ+ community was, at that time, still emerging, gaining acceptance, and struggling for equality. Then, the fledgling and emergent LGBTQ+ community was thus unable to collectively devote time and energy into identifying and preserving places that were historically significant or meaningful as they struggled to gain a collective voice and unified identity. Even though gay places were listed on the National Register of Historic Places and the National Historic Landmark lists after the National Historic Preservation Act of 1966, the explicit connection to LGBTQ+ heritage was almost always left out of inventory and nomination efforts (National Park Service 2019b). Oftentimes, the connection to LGBTQ+ heritage and history was never explicitly written in inventory and nomination documents, but rather only carried out through local knowledge of the site and oral storytelling on site tours or didactic signage on-site. For this reason, many of the current efforts to commemorate LGBTQ+ places are not necessarily to write nominations to nominate new sites, but rather to explicitly memorialize the LGBTQ+ connections in already-nominated or listed sites.

The LGBTQ Heritage Initiative was expanded in 2014 to include a new theme study to identify places and events associated with LGBTQ+ Americans that would be included in the National Register of Historic Places and listed as National Historic Landmarks (U.S. Department of the Interior 2014a). As mainstream acceptance of LGBTQ+ individuals continues to grow, and as expression of sexual orientation and gender representation has diversified in recent years, the resulting increase in public support for LGBTQ+ rights and civil liberties has enabled bolder and inclusive heritage efforts. Likewise, the body of LGBTQ+ scholarship continues to increase, providing critical support and information necessary to commemorate LGBTQ+ spaces. Sites that were previously not celebrated for their prominence and significance in LGBTQ+ culture and history have lately been designated as "lavender landmarks" (National Park Service 2019b) and by June 2016, ten places were included on the National Register of Historic Places or have been designated as National Historic Landmarks because of their association with or significance to LGBTQ+ history (National Park Service Service 2019b: 02-7). These sites include the Stonewall National Monument (New York City, NY); Dr. Franklin E. Kameny Residence (Washington, DC); James Merrill House (Stonington, CT); Carrington House (Fire Island Pines, NY); Cherry Grove Community House \& Theater (Cherry Grove, NY); The Henry Gerber House (Chicago, IL); Bayard Rustin Residence (New York, NY); Julius' Bar (New York, NY); Edificio Comunidad de Orgullo Gay de Puerto Rico (AKA Pride House; AKA Casa Orgullo) (San Juan, Puerto Rico); and the Furies Collective House (Washington, D.C.). Though efforts in the struggle for LGBTQ+ rights has occurred for decades, the efforts to identify, commemorate, and landmark LGBTQ+ historically significant sites has begun only relatively recently (Fig. 15.2). This delay is explained by LaFrank (2020), the New York State Parks \& Sites Historian for the New York State Historic Preservation Office: 
Historic Preservation of LGBTQ+ Sites Timeline

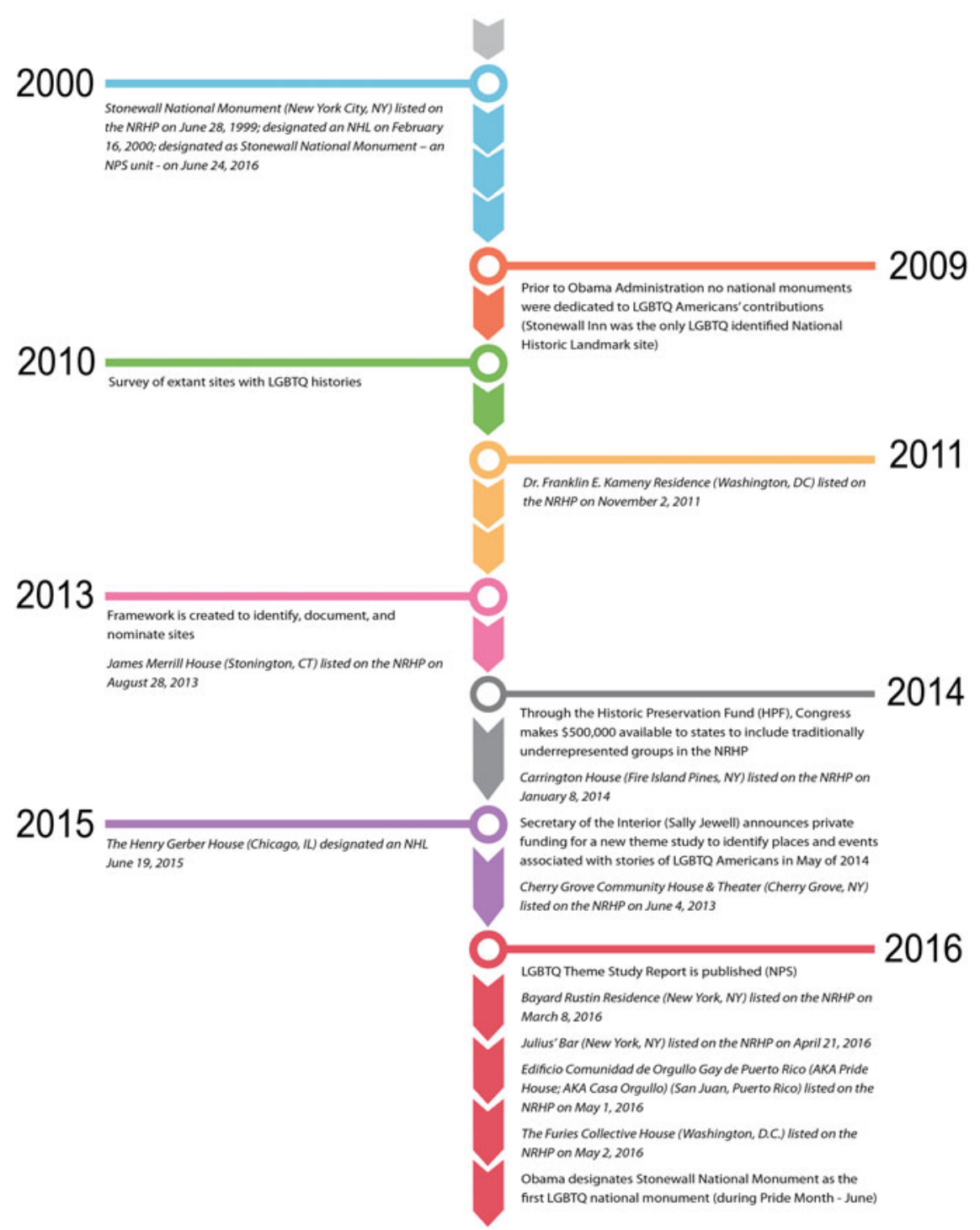

Fig. 15.2 Timeline showing progression of LGBTQ+ preserved sites. The sites listed in the timeline are those that are either on the NRHP or NHL, intentionally designated for their importance as a historically significant LGBTQ site (Source Timeline by authors) 
I think it parallels what was happening in society. It took a long time for LGBTQ rights. First we had "don't ask, don't tell" during Clinton and then we gradually had same sex marriage. And whether we like it or not, these things take a long time; society takes a while to accept things like this and for people to become understanding and get used to it. (LaFrank 2020)

\subsubsection{Initial Results of the LGBTQ Heritage Initiative}

One of the early outcomes of the LGBTQ Heritage Initiative was the creation of a national map of places across the country significant to LGBTQ+ history and heritage (Fig. 15.3). This map is part of an ongoing crowd-sourced exercise in which the public is encouraged by the LGBTQ Heritage Initiative and the National Park Service to contribute specific sites to the inclusive narrative of the LGBTQ+ community (National Park Service 2019e). While initiated as part of the LGBTQ Heritage Initiative, this map is maintained as a joint effort of the National Park Service, Quist, and the Rainbow Heritage Network. A number of sites appear on this map that were previously nominated for being historically significant (based on National Park

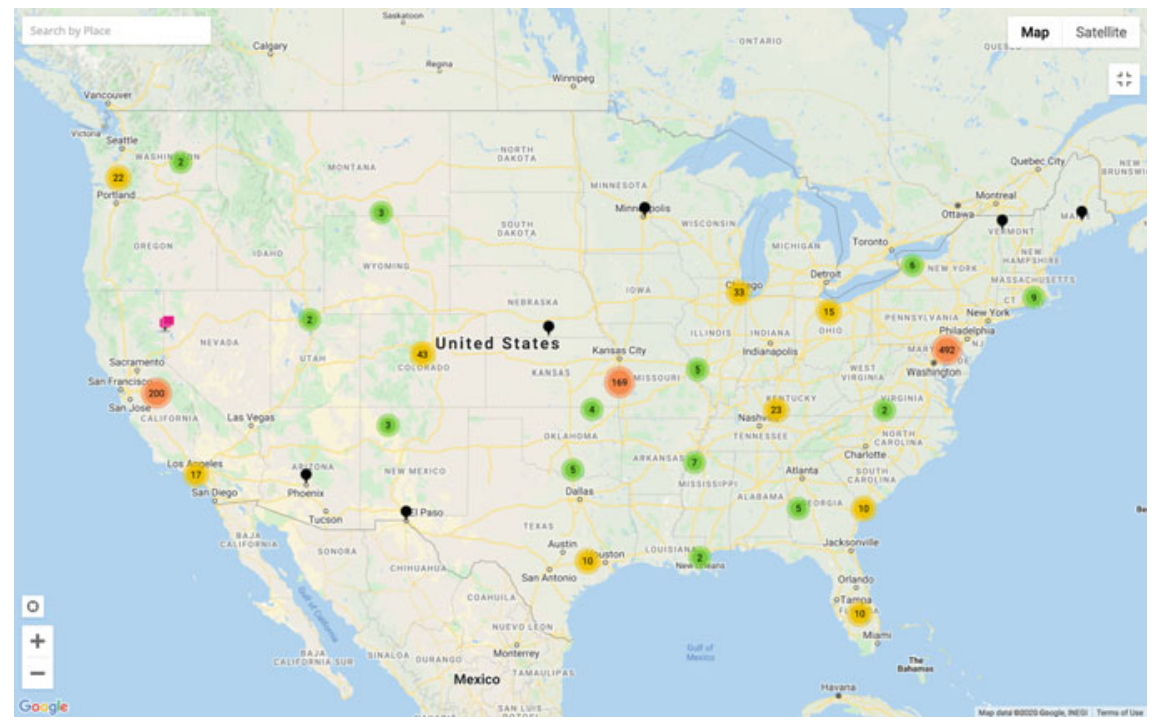

Fig. 15.3 Map created using HistoryPin.org as a part of the NPS LGBTQ Heritage Initiative, part of an ongoing project in which people are asked to contribute to this inclusive story of the LGBTQ community in order to support an inclusive history (Source National Park Service, Quist, and Rainbow Heritage Network, 2015, pubic domain image) 
Service criteria for the National Register of Historic Places or National Historic Landmark listings), ${ }^{5}$ however, the relevance of these sites as LGBTQ+-specific historical sites was mostly omitted on original nomination forms.

The LGBTQ+ mapping project helps to make LGBTQ+ heritage and history more visible. The grassroots, bottom-up approach to collecting significant history is part of LGBTQ+ heritage that has allowed for inclusion and connectivity in the process of making America's history more inclusive. As of 2020 the LGBTQ+ mapping project has listed 1,161 sites (National Park Service, Quist, and Rainbow Heritage Network 2016) and collects additional information about existing sites that have been previously listed, as well as information about potential sites that have not yet been identified. The novel, collective, and contributory method for assembling information ensures broad access to a thorough, inclusive history about LGBTQ+ places and ensures the history and importance of these places is not lost (National Park Service 2019a).

Another significant advancement stemming from the LGBTQ Heritage Initiative was the publication of a 1,262-page theme study by the National Park Service that documents the national LGBTQ+ experience (Fig. 15.4) in 2016. This document represents the first account of the LGBTQ+ community in the history of the United States (National Park Service 2019b) by the U.S. Federal Government. This 2016 LGBTQ theme study utilized a new methodology—compared to that of previous theme studies - to effectively illustrate the degree to which the LGBTQ+ community has been underrepresented in the National Register of Historic Places and National Historic Landmark programs. The 2016 LGBTQ theme study utilized several methodological approaches including "modeling the telling of LGBTQ history using place; a commitment to community, including being accessible and useful and in recognizing many LGBTQ communities in the United States; the importance of multiple voices; the need to acknowledge and respect identity; and the inclusion of difficult and painful histories" (National Park Service 2019b: 02-22-23). Typically, theme studies include previously listed places to illustrate how the properties associated with the theme meet program requirements. In the case of the 2016 LGBTQ theme study, however, this method proved to be ineffective because so few (only about ten) LGBTQ-inclusive sites were listed. The 2016 LGBTQ theme study models and demonstrates ways in which LGBTQ+ history could be recounted by using place-based examples and providing information on how to link those histories with National Register of Historic Places and National Historic Landmark program guidelines and requirements for the future listing of properties (National Park Service 2019b).

The 2016 LGBTQ theme study is organized into six sections (Introduction, Preserving LGBTQ History, Inclusive Stories, Themes, Places, and Legacy) and emphasizes central nature of the LGBTQ+ dynamic histories and experiences. The study aims to connect the complex, multi-polar, intersectional histories of LGBTQ+

\footnotetext{
${ }^{5}$ Specific details about NPS criteria for National Register of Historic Places listings (National Park Service Cultural Resources 1990) and National Historic Landmarks listings (National Park Service Cultural Resources 1999).
} 


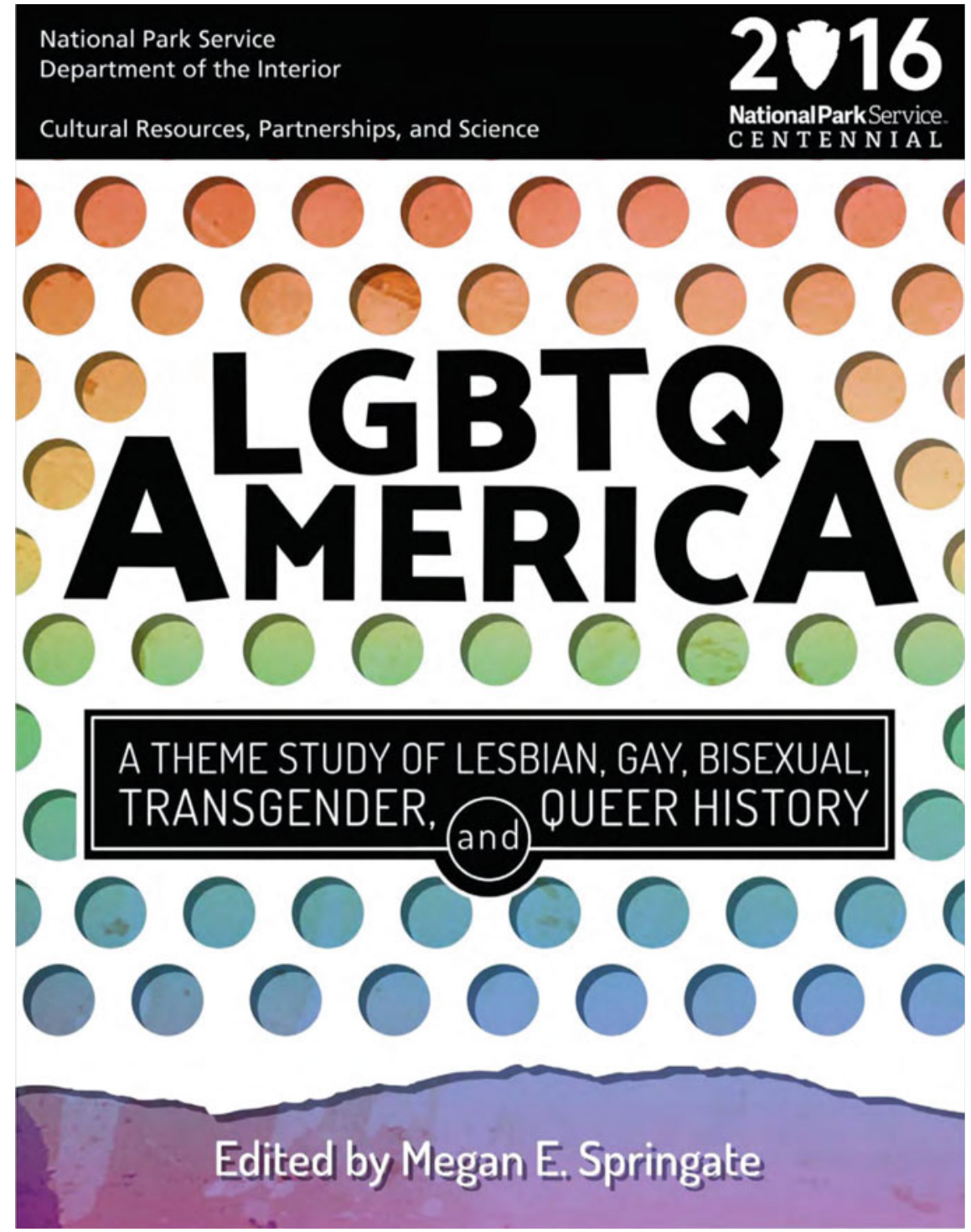

Fig. 15.4 Cover of "LGBTQ America: A Theme Study of Lesbian, Gay, Bisexual, Transgender, and Queer History," a 1,262-page, multi-chapter report published in 2016 as part of the LGBTQ Heritage Initiative (Source National Park Service 2019b, public domain image) 
communities to that of the broader United States history. Through the six in-depth sections, this theme study makes clear connections to broader American history, places, and landscapes throughout the country in ways that the LGBTQ+ community had previously been excluded. The manner by which the theme study begins to illustrate connections that had not been explicit in the past makes the completion and publication of the 2016 LGBTQ theme study an important first step toward increasing the number of sites that commemorate and celebrate LGBTQ+ history and heritage, increasing visibility and inclusion for the LGBTQ+ community. This initial step, made possible by funding from the United States government, was a success which has gained much-needed traction and momentum for the LGBTQ+ community toward a collective effort to uncover and tell the histories and experiences of LGBTQ+ Americans.

The significant work accomplished as a result of the 2016 LGBTQ theme study and the effort to have LGBTQ+ sites intentionally listed in the National Register of Historic Places and National Historic Landmarks - for the reason of being significant to LGBTQ+ history-is not just thanks to the people directly working on these projects, but also to decades of tireless advocacy by the LGBTQ+ community, activists, and allies. These steps to make historic preservation more accessible, equitable, and inclusive has resulted in the greater visibility and awareness of LGBTQ+ untold histories through historic sites and structures, museums, interpretive sites, and city streets.

\subsection{Current Status of the Preservation of LGBTQ+ Sites}

Despite important advances and structural support, according to the National Park Service Heritage data (2014-2019), no grant programs funded through the LGBTQ Heritage Initiative currently support the research and/or preservation of individual LGBTQ+ historic sites (National Park Service 2019a). This arrangement differs from other historic preservation efforts in that some other preservation initiatives and programs provide dedicated funding set aside for specific initiatives and programs. That is not to imply that LGBTQ+ sites cannot apply for awards from other, more generic pools of funding, but the means by which funding is available to protect, commemorate, and memorialize LGBTQ+ sites remains opaque. While sources of funding for LGBTQ+ sites do exist, the regulations and procedures for obtaining funding are unusually cumbersome. For example, one extra burden required by many of these funding sources is that the site is already listed as a National Historic Landmark or is already included in the National Register of Historic Places, each a laborious effort in their own right. Some funding sources which remain available for LGBTQ+ historic sites outside of Federal programs include state and local governments, private foundations, historic tax credits, historic trusts, and the National Trust for Historic Preservation (National Park Service 2019a).

Efforts to incorporate historically underrepresented groups in the National Register of Historic Places and National Historic Landmark listings have been made 
by the United States Congress by providing funding available to states through the Underrepresented Community (URC) Grant Program (National Park Service 2020b). Managed by the National Park Service and funded by the Historic Preservation Fund $(\mathrm{HPF})^{6}$, the Underrepresented Community Grant Program was created to provide resources to traditionally underrepresented groups in the National Register of Historic Places for projects including surveys and inventories of historic properties associated with these communities (National Park Service 2019a, 2020b). The Underrepresented Community Grant program guidelines indicate, "grants are awarded through a competitive process and do not require non-Federal match. Eligible applicants are limited to State Historic Preservation offices, Federally Recognized Tribes, Alaska Natives, and Native Hawaiian Organizations, and Certified Local Governments" (National Park Service 2020b). Theoretically, these funds could be used by state offices of historic preservation and other governmental agencies to protect and memorialize LGBTQ+ sites.

In each of the fiscal years 2014 through 2019, Congress appropriated $\$ 500,000$ for grants that provided funding for surveys, inventories, and the designation of properties associated with underrepresented communities in the National Register of Historic Places and National Historic Landmark listings (National Park Service 2014; U.S. Department of the Interior 2014b). ${ }^{7}$ See Fig. 15.5. The Underrepresented Community Grant Program made available a total of $\$ 750,000$ in grant funding for the 2020 fiscal year. This grant program has provided funding to 75 projects over the past six years (from 2014 to 2019) across 34 states (Table 15.1). ${ }^{8}$ A wide range of agencies have received funding from this grant program including, state departments and preservation offices, municipalities, indigenous tribes and villages, historic and archeological districts, and historical societies. The grant award per project has ranged from $\$ 3,847$ to $\$ 72,000$ with projects being awarded an average of $\$ 40,979$ (the median project award was $\$ 43,158)$. $^{9}$

Since the beginning of the Underrepresented Community Grant Program in 2014, approximately 10-18 projects have been awarded funding each year. Underrepresented communities receiving funding for heritage projects over the past six years include LGBTQ+, African American, Indigenous communities, American Latina/Latino, Asian American, and Pacific Islander, and Women. Table 15.2 and Fig. 15.6 provide a summary of the number of projects each underrepresented community has received along with the total funding dollars per year per category and since the Underrepresented Community Grant began in 2014.

\footnotetext{
${ }^{6}$ The Historic Preservation Tax Fund is not supported with tax dollars, but rather supported by revenue from Federal oil leases on the Outer Continental Shelf (National Park Service 2020b).

${ }^{7}$ Three projects in 2015 and one project in 2017 that listed multiple Underrepresented Community Categories. These are noted in italicized text.

${ }^{8}$ Included in the 34 states is the District of Columbia and the Federated States of Micronesia National Government.

${ }^{9}$ The 2019 dataset for the Underrepresented Community Grant Program did not include the individual monetary awards distributed for each project, thus these values are calculated using the figures from 2014 to 2018.
} 
Map of Underrepresented Community (URC) Grants Awarded per State (2014 to 2019)

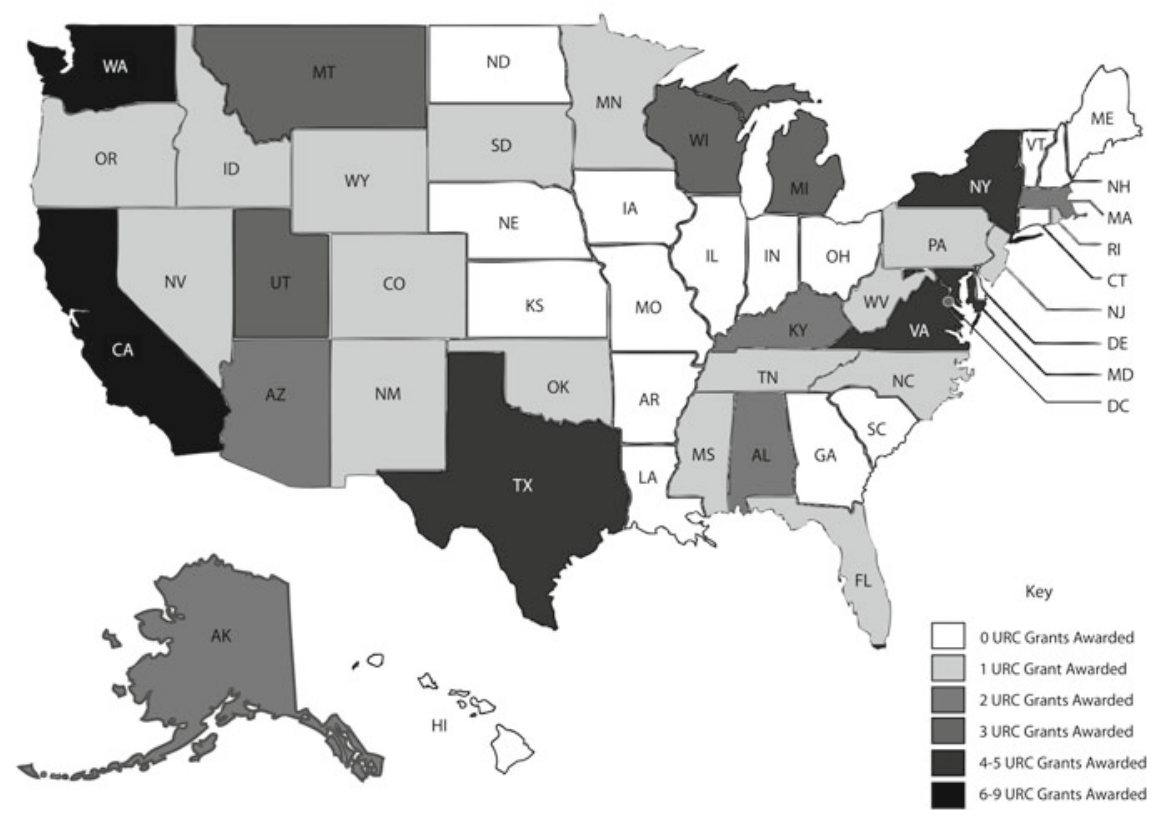

Fig. 15.5 Number of Underrepresented Community Grants awarded per state from 2014 to 2019 (Source Map by authors)

Based on the analysis presented in Table 15.2 and Fig. 15.6, the LGBTQ+ community receives considerably less funding, both in terms of the number of projects (7.9 percent of the total number of projects funded since 2014) as well as the amount of funding (8.4 percent of total available funding since 2014). In fact, all other communities (except projects related to women) received more funding than the LGBTQ+ group. It should also be noted that four of the 6.2 total projects related to LGBTQ+ heritage have been part of a four-phase project for New York City (comprising over 50 percent of the funding awarded to LGBTQ+ projects; approximately $\$ 125,000$ out of the total $\$ 211,000)$. This is not to imply that funding is not necessarily being approved for projects related to the LGBTQ+ community, as the lack of projects funded could be related to a lack of applications for funding. However, anecdotal data implies that indeed, LGBTQ+ projects do indeed receive considerably less funding, despite a notable number of applications.

\subsubsection{Constancy of Application}

LGBTQ+-significant places and gay neighborhoods are now considered "worth preserving" due to a heightened awareness as a result of increased media coverage 
Table 15.1 Table showing list of Underrepresented Community (URC) grant program awardees in each year since the start of the program in 2014 to 2019 (U.S. Department of the Interior 2014a, b, 2017a, b, 2019, National Park Service 2020c)

List of Underrepresented Community (URC) grant program awardees (2014-2019)

\begin{tabular}{|c|c|c|c|c|}
\hline FY & State & Grantee/Project & Category & $\begin{array}{l}\text { Grant } \\
\text { Award (\$) }\end{array}$ \\
\hline 2014 & California & $\begin{array}{l}\text { California State Historic } \\
\text { Preservation Office }\end{array}$ & $\begin{array}{l}\text { American } \\
\text { Latina/Latino } \\
\text { Heritage }\end{array}$ & $\$ 30,079$ \\
\hline 2014 & Idaho & $\begin{array}{l}\text { Rapid River Fishery in } \\
\text { Partnership with the Nez } \\
\text { Pierce Tribe }\end{array}$ & Indigenous Heritage & $\$ 25,090$ \\
\hline 2014 & Kentucky & $\begin{array}{l}\text { Nomination of Whiskey Row } \\
\text { Historic District and Henry } \\
\text { Clay Hotel }\end{array}$ & LGBTQ+ Heritage & $\$ 25,000$ \\
\hline 2014 & Massachusetts & Boston & $\begin{array}{l}\text { Asian American and } \\
\text { Pacific Islander } \\
\text { Heritage }\end{array}$ & $\$ 25,000$ \\
\hline 2014 & Maryland & Baltimore & $\begin{array}{l}\text { African American } \\
\text { Heritage }\end{array}$ & $\$ 60,000$ \\
\hline 2014 & Montana & $\begin{array}{l}\text { Identifying African American } \\
\text { Heritage Places }\end{array}$ & $\begin{array}{l}\text { African American } \\
\text { Heritage }\end{array}$ & $\$ 27,788$ \\
\hline 2014 & New Mexico & $\begin{array}{l}\text { Tribal and Pueblo Nations } \\
\text { Preservation Summit }\end{array}$ & Indigenous Heritage & $\$ 59,620$ \\
\hline 2014 & New York & New York City & LGBTQ+ Heritage & $\$ 49,999$ \\
\hline 2014 & Rhode Island & College Hill Historic District & $\begin{array}{l}\text { African American } \\
\text { Heritage }\end{array}$ & $\$ 25,000$ \\
\hline 2014 & South Dakota & $\begin{array}{l}\text { Architectural Surveys of } \\
\text { Shannon County }\end{array}$ & Indigenous Heritage & $\$ 26,000$ \\
\hline 2014 & Utah & $\begin{array}{l}\text { Iosepa Polynesian } \\
\text { Archeological District }\end{array}$ & $\begin{array}{l}\text { Asian American and } \\
\text { Pacific Islander } \\
\text { Heritage }\end{array}$ & $\$ 42,050$ \\
\hline 2014 & Virginia & $\begin{array}{l}\text { Virginia Indians National } \\
\text { Register Project }\end{array}$ & Indigenous Heritage & $\$ 70,000$ \\
\hline 2014 & Washington & Yakima Valley and Seattle & $\begin{array}{l}\text { American } \\
\text { Latina/Latino } \\
\text { Heritage }\end{array}$ & $\$ 34,374$ \\
\hline 2015 & Alaska & $\begin{array}{l}\text { Organized Village of Kake } \\
\text { Nomination Project }\end{array}$ & Indigenous Heritage & $\$ 33,153$ \\
\hline 2015 & California & $\begin{array}{l}\text { City of Los Angeles Asian } \\
\text { American Historic Context } \\
\text { Project }\end{array}$ & $\begin{array}{l}\text { Asian American and } \\
\text { Pacific Islander } \\
\text { Heritage }\end{array}$ & $\$ 72,000$ \\
\hline
\end{tabular}


Table 15.1 (continued)

\begin{tabular}{|c|c|c|c|c|}
\hline \multicolumn{5}{|c|}{ List of Underrepresented Community (URC) grant program awardees (2014-2019) } \\
\hline 2015 & California & $\begin{array}{l}\text { City of San Francisco Civil } \\
\text { Rights Project }\end{array}$ & $\begin{array}{l}\text { African American, } \\
\text { Asian American, } \\
\text { Latino/a American, } \\
\text { LGBTQ+, and } \\
\text { Women's Heritage }\end{array}$ & $\$ 55,000$ \\
\hline 2015 & Maryland & $\begin{array}{l}\text { Calvert County Piscataway } \\
\text { Indian Archaeology Multiple } \\
\text { Property Nomination Project }\end{array}$ & Indigenous Heritage & $\$ 47,000$ \\
\hline 2015 & Minnesota & $\begin{array}{l}\text { Fort Snelling Historic District } \\
\text { National Historic Landmark } \\
\text { Update Project }\end{array}$ & $\begin{array}{l}\text { African American, } \\
\text { Asian American, } \\
\text { Indigenous, and } \\
\text { Women's Heritage }\end{array}$ & $\$ 60,000$ \\
\hline 2015 & Montana & $\begin{array}{l}\text { Butte, Montana Ethnic Atlas, } \\
\text { and National Register } \\
\text { Nomination Project }\end{array}$ & $\begin{array}{l}\text { African American } \\
\text { and Asian American } \\
\text { Heritage }\end{array}$ & $\$ 56,000$ \\
\hline 2015 & New York & $\begin{array}{l}\text { New York City Casitas Survey } \\
\text { and Nomination Project }\end{array}$ & $\begin{array}{l}\text { American } \\
\text { Latina/Latino } \\
\text { Heritage }\end{array}$ & $\$ 46,000$ \\
\hline 2015 & North Carolina & $\begin{array}{l}\text { African American Resources } \\
\text { in North Carolina Nomination } \\
\text { Project }\end{array}$ & $\begin{array}{l}\text { African American } \\
\text { Heritage }\end{array}$ & $\$ 70,000$ \\
\hline 2015 & Virginia & Spotsylvania County Heritage & $\begin{array}{l}\text { African American } \\
\text { Heritage }\end{array}$ & $\$ 3,847$ \\
\hline 2015 & Wisconsin & $\begin{array}{l}\text { Wolf River Archaeological } \\
\text { District National Register } \\
\text { Nomination Project }\end{array}$ & Indigenous Heritage & $\$ 57,000$ \\
\hline 2016 & Alabama & $\begin{array}{l}\text { Alabama Historical } \\
\text { Commission }\end{array}$ & $\begin{array}{l}\text { African American } \\
\text { Heritage }\end{array}$ & $\$ 33,361$ \\
\hline 2016 & Arizona & White Mountain Apache Tribe & Indigenous Heritage & $\$ 48,526$ \\
\hline 2016 & California & State of California & $\begin{array}{l}\text { Asian American and } \\
\text { Pacific Islander } \\
\text { Heritage }\end{array}$ & $\$ 50,000$ \\
\hline 2016 & Colorado & $\begin{array}{l}\text { State Historical Society of } \\
\text { Colorado }\end{array}$ & $\begin{array}{l}\text { American } \\
\text { Latina/Latino } \\
\text { Heritage }\end{array}$ & $\$ 43,158$ \\
\hline 2016 & $\begin{array}{l}\text { District of } \\
\text { Columbia }\end{array}$ & $\begin{array}{l}\text { District of Columbia Office of } \\
\text { Planning }\end{array}$ & LGBTQ+ Heritage & $\$ 50,000$ \\
\hline 2016 & New York & $\begin{array}{l}\text { New York State Office of } \\
\text { Parks, Recreation, \& Historic } \\
\text { Preservation Office - Phase } 2\end{array}$ & LGBTQ+ Heritage & $\$ 49,999$ \\
\hline
\end{tabular}


Table 15.1 (continued)

\begin{tabular}{|c|c|c|c|c|}
\hline \multicolumn{5}{|c|}{ List of Underrepresented Community (URC) grant program awardees (2014-2019) } \\
\hline 2016 & Pennsylvania & $\begin{array}{l}\text { Pennsylvania Historical \& } \\
\text { Museum Commission }\end{array}$ & $\begin{array}{l}\text { African American } \\
\text { Heritage }\end{array}$ & $\$ 30,000$ \\
\hline 2016 & Texas & City of Socorro & $\begin{array}{l}\text { American } \\
\text { Latina/Latino } \\
\text { Heritage }\end{array}$ & $\$ 19,800$ \\
\hline 2016 & Virginia & $\begin{array}{l}\text { Virginia Department of } \\
\text { Historic Resource }\end{array}$ & $\begin{array}{l}\text { African American } \\
\text { Heritage }\end{array}$ & $\$ 50,000$ \\
\hline 2016 & Washington & $\begin{array}{l}\text { Confederated Tribes of the } \\
\text { Colville Reservation }\end{array}$ & Indigenous Heritage & $\$ 49,992$ \\
\hline 2016 & Washington & $\begin{array}{l}\text { State of Washington } \\
\text { Department of Archaeology \& } \\
\text { Historic Preservation }\end{array}$ & $\begin{array}{l}\text { American } \\
\text { Latina/Latino } \\
\text { Heritage }\end{array}$ & $\$ 50,000$ \\
\hline 2016 & Wisconsin & Wisconsin Historical Society & $\begin{array}{l}\text { African American } \\
\text { Heritage }\end{array}$ & $\$ 25,164$ \\
\hline 2017 & Alaska & Igiugig Village & Indigenous Heritage & $\$ 43,479$ \\
\hline 2017 & Alaska & $\begin{array}{l}\text { State of Alaska Division of } \\
\text { Parks \& Outdoor Recreation }\end{array}$ & Indigenous Heritage & $\$ 48,668$ \\
\hline 2017 & Arizona & Arizona Department of Parks & $\begin{array}{l}\text { American } \\
\text { Latina/Latino } \\
\text { Heritage }\end{array}$ & $\$ 42,760$ \\
\hline 2017 & California & State of California & Indigenous Heritage & $\$ 41,872$ \\
\hline 2017 & California & Pala Band of Mission Indians & Indigenous Heritage & $\$ 48,295$ \\
\hline 2017 & Maryland & $\begin{array}{l}\text { Maryland Department of } \\
\text { Planning/Maryland Historical } \\
\text { Trust }\end{array}$ & Women's Heritage & $\$ 30,500$ \\
\hline 2017 & New Jersey & City of Paterson & $\begin{array}{l}\text { African American } \\
\text { Heritage }\end{array}$ & $\$ 35,000$ \\
\hline 2017 & Tennessee & City of Memphis & $\begin{array}{l}\text { African American } \\
\text { Heritage }\end{array}$ & $\$ 45,000$ \\
\hline 2017 & Texas & City of Austin & $\begin{array}{l}\text { African American, } \\
\text { American } \\
\text { Latina/Latino } \\
\text { Heritage }\end{array}$ & $\$ 43,200$ \\
\hline 2017 & Texas & County of Milam & $\begin{array}{l}\text { American } \\
\text { Latina/Latino } \\
\text { Heritage }\end{array}$ & $\$ 50,000$ \\
\hline 2017 & Virginia & $\begin{array}{l}\text { Virginia Department of } \\
\text { Historic Resources }\end{array}$ & Indigenous Heritage & $\$ 34,486$ \\
\hline 2017 & Washington & City of Pasco & $\begin{array}{l}\text { African American } \\
\text { Heritage }\end{array}$ & $\$ 20,000$ \\
\hline
\end{tabular}


Table 15.1 (continued)

\begin{tabular}{|c|c|c|c|c|}
\hline \multicolumn{5}{|c|}{ List of Underrepresented Community (URC) grant program awardees (2014-2019) } \\
\hline 2017 & Washington & $\begin{array}{l}\text { Suquamish Indian Tribe of the } \\
\text { Port Madison Reservation }\end{array}$ & Indigenous Heritage & $\$ 16,470$ \\
\hline 2018 & Alabama & $\begin{array}{l}\text { Alabama Historical } \\
\text { Commission }\end{array}$ & $\begin{array}{l}\text { African American } \\
\text { Heritage }\end{array}$ & $\$ 40,000$ \\
\hline 2018 & California & Pala Band of Mission Indians & Indigenous Heritage & $\$ 49,531$ \\
\hline 2018 & $\begin{array}{l}\text { District of } \\
\text { Columbia }\end{array}$ & $\begin{array}{l}\text { District of Columbia Office of } \\
\text { Planning }\end{array}$ & $\begin{array}{l}\text { Asian American and } \\
\text { Pacific Islander } \\
\text { Heritage }\end{array}$ & $\$ 40,000$ \\
\hline 2018 & Kentucky & Louisville Jefferson County & $\begin{array}{l}\text { African American } \\
\text { Heritage }\end{array}$ & $\$ 50,000$ \\
\hline 2018 & Michigan & $\begin{array}{l}\text { Saginaw Chippewa Indian } \\
\text { Tribe of Michigan }\end{array}$ & Indigenous Heritage & $\$ 46,302$ \\
\hline 2018 & Michigan & City of Detroit & $\begin{array}{l}\text { African American } \\
\text { Heritage }\end{array}$ & $\$ 40,000$ \\
\hline 2018 & Montana & Montana Historical Society & $\begin{array}{l}\text { African American } \\
\text { Heritage }\end{array}$ & $\$ 27,052$ \\
\hline 2018 & Nevada & $\begin{array}{l}\text { Nevada Department of } \\
\text { Cultural Affairs/Historic } \\
\text { Preservation Office }\end{array}$ & Women's Heritage & $\$ 46,415$ \\
\hline 2018 & New York & $\begin{array}{l}\text { NYS Office of Parks, } \\
\text { Recreation \& Historic } \\
\text { Preservation-Phase } 3\end{array}$ & LGBTQ+ Heritage & $\$ 25,000$ \\
\hline 2018 & Texas & Ysleta del Sur Pueblo & Indigenous Heritage & $\$ 44,439$ \\
\hline 2018 & Utah & Utah Division of State History & $\begin{array}{l}\text { American } \\
\text { Latina/Latino } \\
\text { Heritage }\end{array}$ & $\$ 36,000$ \\
\hline 2018 & Washington & Muckleshoot Indian Tribe & Indigenous Heritage & $\$ 30,420$ \\
\hline 2018 & West Virginia & $\begin{array}{l}\text { West Virginia Department of } \\
\text { Arts, Culture \& History }\end{array}$ & $\begin{array}{l}\text { African American } \\
\text { Heritage }\end{array}$ & $\$ 24,841$ \\
\hline 2019 & California & $\begin{array}{l}\text { Federated Indians of Graton } \\
\text { Rancheria }\end{array}$ & Indigenous Heritage & $\mathrm{n} / \mathrm{a}$ \\
\hline 2019 & California & $\begin{array}{l}\text { San Pasqual Band of Mission } \\
\text { Indians }\end{array}$ & Indigenous Heritage & $\mathrm{n} / \mathrm{a}$ \\
\hline 2019 & $\begin{array}{l}\text { District of } \\
\text { Columbia }\end{array}$ & $\begin{array}{l}\text { District of Columbia Office of } \\
\text { Planning }\end{array}$ & Women's Heritage & $\mathrm{n} / \mathrm{a}$ \\
\hline 2019 & Florida & $\begin{array}{l}\text { City of Sarasota Newtown } \\
\text { Conservation Historic District }\end{array}$ & $\begin{array}{l}\text { African American } \\
\text { Heritage }\end{array}$ & $\mathrm{n} / \mathrm{a}$ \\
\hline
\end{tabular}


Table 15.1 (continued)

\begin{tabular}{|c|c|c|c|c|}
\hline \multicolumn{5}{|c|}{ List of Underrepresented Community (URC) grant program awardees (2014-2019) } \\
\hline 2019 & $\begin{array}{l}\text { Federated States } \\
\text { of Micronesia }\end{array}$ & $\begin{array}{l}\text { Federated States of } \\
\text { Micronesia National } \\
\text { Government-Mahkontowe: } \\
\text { A Micronesian Landscape }\end{array}$ & $\begin{array}{l}\text { Asian American and } \\
\text { Pacific Islander } \\
\text { Heritage }\end{array}$ & $\mathrm{n} / \mathrm{a}$ \\
\hline 2019 & Massachusetts & $\begin{array}{l}\text { Commonwealth of } \\
\text { Massachusetts }\end{array}$ & $\begin{array}{l}\text { African American } \\
\text { Heritage }\end{array}$ & $\mathrm{n} / \mathrm{a}$ \\
\hline 2019 & Maryland & $\begin{array}{l}\text { Maryland Department of } \\
\text { Planning, Maryland Historical } \\
\text { Trust }\end{array}$ & $\begin{array}{l}\text { Asian American and } \\
\text { Pacific Islander } \\
\text { Heritage }\end{array}$ & $\mathrm{n} / \mathrm{a}$ \\
\hline 2019 & Michigan & Michigan Strategic Fund & $\begin{array}{l}\text { African American } \\
\text { Heritage }\end{array}$ & $\mathrm{n} / \mathrm{a}$ \\
\hline 2019 & Mississippi & $\begin{array}{l}\text { Mississippi Department of } \\
\text { Archives and History }\end{array}$ & $\begin{array}{l}\text { African American } \\
\text { Heritage }\end{array}$ & $\mathrm{n} / \mathrm{a}$ \\
\hline 2019 & New York & $\begin{array}{l}\text { NYS Office of Parks, } \\
\text { Recreation \& Historic } \\
\text { Preservation -Phase } 4\end{array}$ & LGBTQ+ Heritage & $\mathrm{n} / \mathrm{a}$ \\
\hline 2019 & Oklahoma & Ysleta del Sur Pueblo & Indigenous Heritage & $\mathrm{n} / \mathrm{a}$ \\
\hline 2019 & Oregon & Utah Division of State History & $\begin{array}{l}\text { American } \\
\text { Latina/Latino } \\
\text { Heritage }\end{array}$ & $\mathrm{n} / \mathrm{a}$ \\
\hline 2019 & Utah & $\begin{array}{l}\text { The Northwestern Band of the } \\
\text { Shoshone Nation }\end{array}$ & Indigenous Heritage & $\mathrm{n} / \mathrm{a}$ \\
\hline 2019 & Virginia & City of Virginia Beach & $\begin{array}{l}\text { African American } \\
\text { Heritage }\end{array}$ & $\mathrm{n} / \mathrm{a}$ \\
\hline 2019 & Washington & $\begin{array}{l}\text { Department of Archaeology } \\
\text { and Historic Preservation }\end{array}$ & $\begin{array}{l}\text { Asian American and } \\
\text { Pacific Islander } \\
\text { Heritage }\end{array}$ & $\mathrm{n} / \mathrm{a}$ \\
\hline 2019 & Washington & $\begin{array}{l}\text { Stillaguamish Tribe of Indians } \\
\text { of Washington }\end{array}$ & Indigenous Heritage & $\mathrm{n} / \mathrm{a}$ \\
\hline 2019 & Wisconsin & $\begin{array}{l}\text { Stockbridge-Munsee } \\
\text { Community }\end{array}$ & Indigenous Heritage & $\mathrm{n} / \mathrm{a}$ \\
\hline 2019 & Wyoming & $\begin{array}{l}\text { Wyoming State Historic } \\
\text { Preservation Office }\end{array}$ & $\begin{array}{l}\text { African American } \\
\text { Heritage }\end{array}$ & $\mathrm{n} / \mathrm{a}$ \\
\hline
\end{tabular}

of LGBTQ+ issues, advocacy, and overall greater public acceptance. Therefore it is sensible to expect an increase in the rate in which sites are being intentionally listed as LGBTQ+ sites. However, data indicates that rate of LGBTQ+ listings in the National Register of Historic Places and National Historic Landmarks has remained steady since the original effort to identify, commemorate, and landmark these sites during the Obama administration. While funding for the preservation of historically significant LGBTQ+ sites has continued-but has not increasedduring the Trump administration (Dolkart and Lustbader 2020; Chibbaro Jr and Lou 2018; LaFrank 2020), the outcome of these funding efforts remains uncertain. 


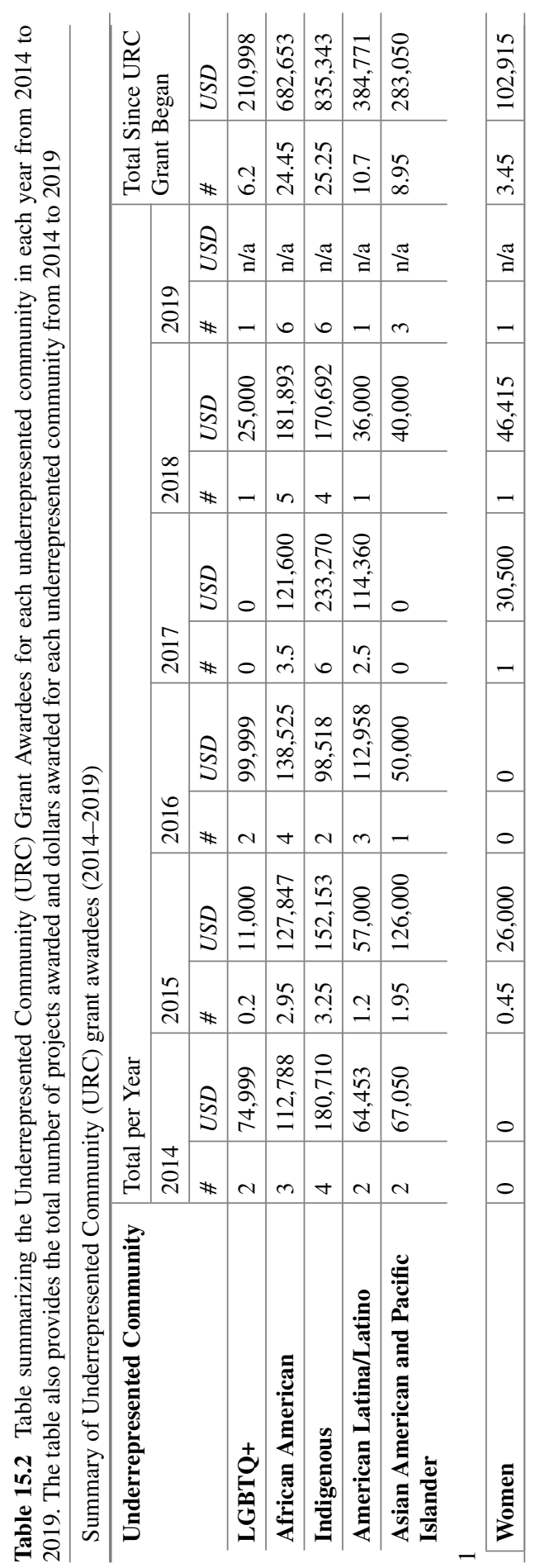




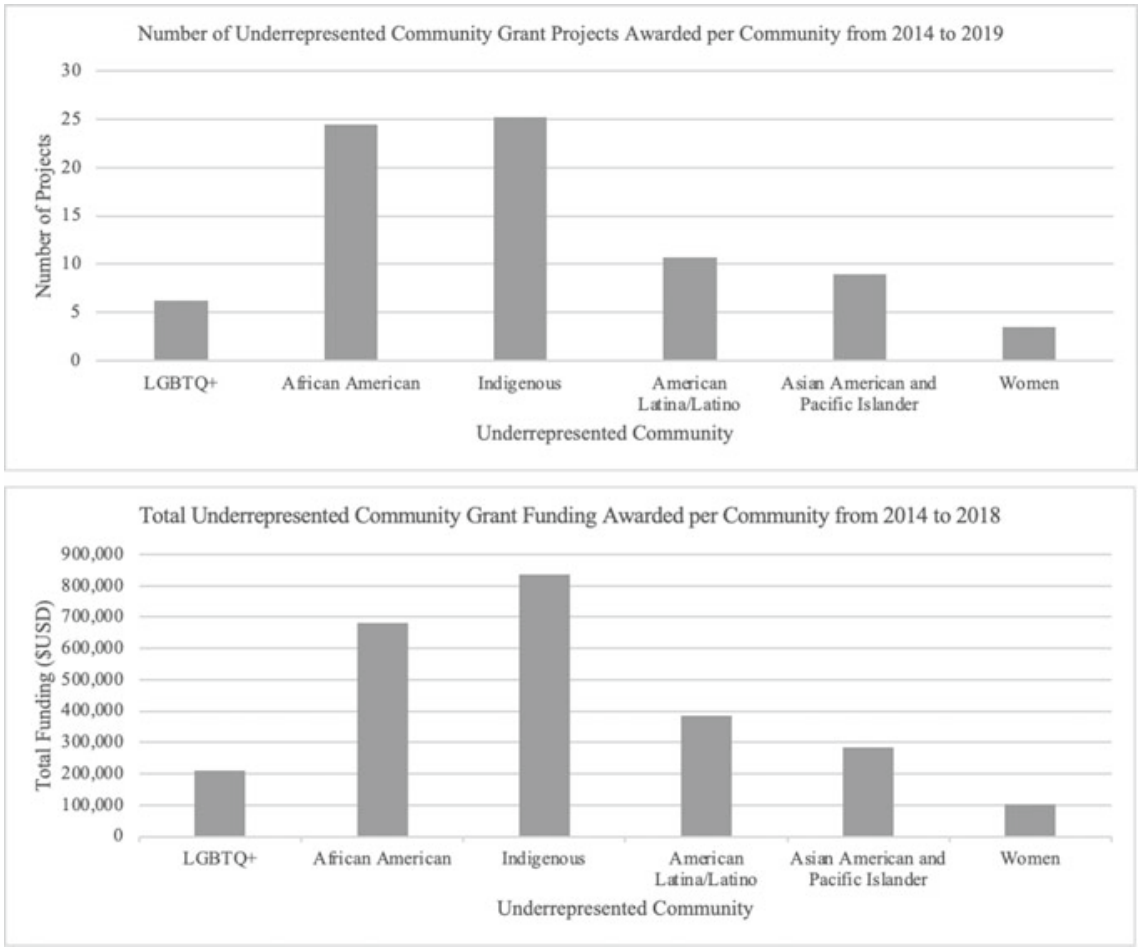

Fig. 15.6 Total number of Underrepresented Community (URC) Grant projects awarded per underrepresented community from 2014 to 2019 (top) and the total monetary URC Grant funds awarded per underrepresented community from 2014 to 2018 (bottom) (Source Graphs by authors)

While funding through the Underrepresented Community Grant has continued and even increased in order to fund more projects focused on preserving the heritage of underrepresented communities, much work remains for the preservation of LGBTQ+ sites.

Evidence of remaining work is evident through the sharp differences in levels of funding and number of LGBTQ+ projects that have been awarded Underrepresented Community Grants compared to the much higher number of projects and more sizable grant amounts awarded to projects for other underrepresented communities. Whether it is due to systemic de-prioritizing LGBTQ+ projects, application barriers for the nomination of LGBTQ+ sites, a low likelihood of acceptance, or the fact that there is simply not enough capacity at the grassroots level to work on these projects, the share of historically significant LGBTQ+ sites commemorated is underwhelming. Considering that many of the significant LGBTQ+ sites are places of violence-just like the numerous battlefields that are meticulously preserved across the United States - the amount of funding for LGBTQ+ sites is notably less to that provided for the preservation and commemoration of battlefields. Specifically, the American Battlefield Preservation Planning (ABPP) Grant (which is just one of the 
many Federal funding sources for battlefields) has provided over \$23 million since 1996 towards preserving significant sites associated with wars on American soil (National Park Service 2020a), where efforts to commemorate, preserve, or memorialize LGBTQ+ sites under the Underrepresented Community Grant program (the only Federal funding source currently available for LGBTQ+ sites) is one-tenth of one percent of that level of support.

\subsection{The Future of Preserving the Past}

Mirroring the fight for LGBTQ+ rights and equality, the process for preserving historic and culturally significant LGBTQ+ sites faces many systemic challenges. Though positive improvements have been made to the funding and protections of LGBTQ+ sites, an opportunity for more significant progress remains. Thus, celebration of the LGBTQ+ communities and assistance in educating the public about the ongoing campaign for LGBTQ+ rights and equality resides in the political views and persuasions of those in power. For now, it seems, a quiet effort to commemorate LGBTQ+ sites, begun under the Obama administration, has escaped budget cuts and scrutiny by the Trump administration.

Despite the obvious inequities in the process of preserving LGBTQ+ sites of historical significance, the effective bottom-up collaboration and grassroots approach led by local communities, groups, and organizations is notable to ensure the preservation and commemoration of LGBTQ+ sites. LGBTQ+ communities across the United States have shown leadership by beginning to identify sites that represent historic and iconic value and are worthy of preservation (National Park Service 2019b). An example of a successful bottom-up approach is the New York City LGBT Historic Sites Project (Fig. 15.7), which has identified specific properties and locations within the New York City metropolitan area that are significant in the struggle for LGBTQ+ rights. The rich stories of these places were largely undocumented at the time the original National Register of Historic Places inventory and nomination forms were completed (Dolkart et al. 2015). The map provides public access to a valuable and continually updated resource that enhances the existing landmark status in a way that is specific to LGBTQ+ history (Dolkart et al. 2015). The New York City LGBT Historic Sites Project provides numerous interactive maps that allow for people to explore this history through various themes and walking tours in order to work towards educating and inspiring future LGBTQ+ generations about the community's contributions to American history and the struggles it has endured and overcome. The New York City LGBT Historic Sites Project provides an example of a comprehensive project that could serve as a model for similar projects in other cities.

Another similar grassroots effort advocating for the preservation and landmarking of historically significant LGBTQ+ sites is the Rainbow Heritage Network (National Park Service 2019b; Rainbow Heritage Network 2015). The Rainbow Heritage Network is a national organization dedicated to the preservation and recognition of 


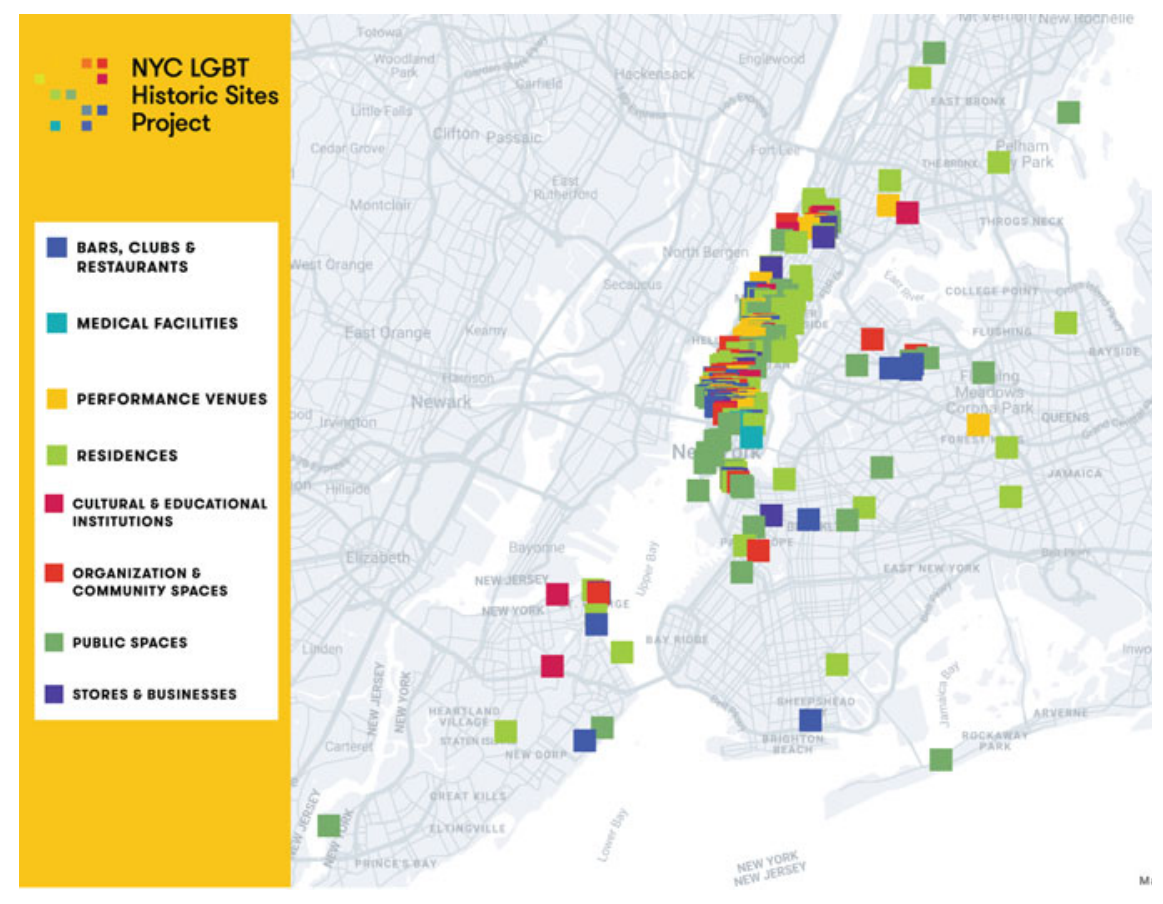

Fig. 15.7 Map created by NYC LGBT Historic Sites Project, a scholarly initiative that began in August 2015 as a way to provide the public with a resource in which they can broaden their knowledge of LGBT history (Source Dolkart, Andrew S., Ken Lustbader, Jay Shockley, and Amanda Davis. 2015)

LGBTQ+ sites, history, and heritage. This group provides opportunities to network, advocate for sites, construct and maintain archives, discuss preservation initiatives, and receive assistance with building connections between repositories and donors of historical material (Rainbow Heritage Network 2015). The efforts put forth by the Rainbow Heritage Network have allowed for several smaller grassroots groups to connect through the compilation of a comprehensive directory in addition to organizing a list of resources intended to support local preservation advocacy efforts at various levels and regions throughout the country.

Unfortunately, bottom-up, grassroots approaches to preservation of LGBTQ+ spaces and neighborhoods have certain limitations. Using grassroots processes for commemorating historically significant LGBTQ+ places involves not just understanding and interpreting historical sites, but doing so within the context of a marginalized, statistically invisible, silenced LGBTQ+ population (Frisch 2021; Hess and Bitterman 2021). Therefore, much of the work that must be completed involves amending existing nominations for the National Register of Historic Places and ensuring that LGBTQ+ history is included in future nominations and ensuring applicants are aware of the ability to seek project funding based on LGBTQ+ historical status or significance. Changing the manner by which LGBTQ+ sites could be 
listed as historic sites will involve proper education on how to properly amend and complete nominations to include the complete and uninhibited history, not simply the history that people believe will be accepted by the National Park Service and the general public. Unfortunately, reviewing all of the previously submitted nominations on the National Register of Historic Places and National Historic Landmark listings to see what sites might have omitted ties to LGBTQ+ histories is a huge undertaking. This effort will require both a substantial investment of time and significant resources to fund the work that needs to be completed.

The burden and expense of identifying and landmarking LGBTQ+ significant sites, buildings, and neighborhoods with either the existing National Register of Historic Places or National Historic Landmark program is initiated and performed locally, thus resulting in a time lag between site identification and the site receiving landmark status. Delays and time lags can expose the nomination and designation process to political pressure. The process of landmarking a site, regardless of level (local, state, or federal) is costly and lengthy, thus emphasizing the need for LGBTQ+ community members, allies, and advocates to become educated with the nomination process and develop skills necessary to assist with preparing landmark nominations. These supporters must be willing to remain connected to the process for a long duration. The development of relevant skills is vital to the progress of incorporating LGBTQ+ histories into previous and future nominations. Since anyone can prepare and submit nomination forms, the review of draft nominations by state and federal historic preservation office staff is vital to maintaining quality control. Unfortunately, administration of these programs have been chronically understaffed (National Park Service 2019b) which compounds barriers to securing funding for LGBTQ+ sites. Broadening the scope of those who are able to share their knowledge regarding LGBTQ+ contexts and histories, and ensuring that there is engagement of LGBTQ+ expertise during the review process, will allow for the increased contribution and visibility of historically significant gay places.

While various steps are being taken simultaneously at local, state, and national levels, several steps can be addressed in order to ensure that LGBTQ+ sites are appropriately celebrated and commemorated so that future generations may connect with these important heritage touchpoints and histories, including:

- Encourage LGBTQ+ groups to apply for funding and educate grassroots entities on how to engage the application process. Because other types of projects (i.e., historic preservation projects receiving tax credits) tend to be more lucrative commercial undertakings, historic preservationists tend to focus more on these types of nominations rather than cultural or heritage projects.

- Ensure written nominations (National Historic Landmarks or National Register of Historic Places) focus equally on site history and physical attributes of sites. The preservation of significant sites is not just about the site looking "historically pretty." 
- Encourage the integration of LGBTQ+ history into school curriculums and preservation survey work. This is often challenging, especially if a historic preservationist is not completely familiar with a site and is apt to overlook "untold histories."

- Focus efforts on recording oral histories before the aging LGBTQ+ populations are gone forever.

- Encourage more professional organizations, like businesses, corporations, and institutions, to be more receptive to putting forward LGBTQ+ preservation and commemmoration initiatives as priorities.

- Incorporate LGBTQ+ heritage more into the daily work of preservationists, educate the public about LGBTQ+ history when appropriate on tours, and integrate LGBTQ+ stories into projects and written nominations.

- Expand the celebration of LGBTQ+ history and heritage beyond the months of June (LGBTQ+ Pride Month) and October (LGBTQ+ History Month) in the United States.

- Utilize new communication tools through social media to repackage otherwise static historic documents and nominations to relate history and heritage to people today.

While a consistent effort towards commemorating historically significant gay places has been made, a significant amount of work remains to incorporate and integrate LGBTQ+ histories into the various historic preservation programs at all levels of programming (local, state, and federal).

\subsection{Takeaway Messages}

The analysis in this chapter of work being done to commemorate and preserve historically significant LGBTQ+ sites produces the following three takeaway messages:

\section{Takeaway message 1. Creativity should be used in understanding and applying nomination criteria to LGBTQ+ spaces; the Stonewall nomination utilized the framework in which battlefield nominations are written.}

One of the ways in which more LGBTQ+ histories can be incorporated into National Register and National Historic Landmark nominations - and in historic preservation work more generally-is through employing more creative ways by which significant LGBTQ+ places are situated and contextualized in historical narrative. Often for preservationists the propensity to disregard buildings or sites that are not "architecturally rich" or "aesthetically pleasing" becomes evident in the nomination process that too often focuses on the physicality of a structure during its period of significance. This is not to say, however, that sites that are no longer extant should not be nominated, but rather culturally rich sites should be considered with a different perspective, similar to how the nomination for 
Stonewall ingeniously utilized a framework typically used to write and nominate battlefields. This creative approach better captures the historical significance in the struggle for LGBTQ+ rights and produced a successful nomination. Just as with a battlefield nomination, the Stonewall nomination described different stagings and movement of the two sides (in this case police and LGBTQ+ protesters). Additionally, the authors interviewed numerous people and wove together a descriptive account of how the uprising occurred in such a way that the written nomination document left a reader with little doubt that the site was historically significant (Carter et al. 1999).

Takeaway message 2. Funding is available for commemorating and preserving LGBTQ+ sites, however, the mechanism to apply for funding is not widely disseminated among smaller groups or organizations.

Although funding for the nomination of sites to be listed on the National Register of Historic Places and as National Historic Landmarks is available, the mechanism to apply for funding is unfortunately not widely publicized in a manner that allows for those who do not work in the field of preservation to learn about the availability of funding, the funding cycle, or how to apply. While there are LGBTQ+ groups that may be interested in applying for preservation funds to commemorate historically significant places of LGBTQ+ heritage, the application process remains an unwieldy task that requires significant time and resources. The process of researching and preparing nominations is not simple, and completing the application process is fully dependent on the work of preservationists, professionals, activists, and engaged community members, ideally with oversight and assistance from state historic preservation offices. State historic preservation offices have become inundated with projects that are more profitable for developers, including preservation projects receiving tax credits, and these typically take precedence. A common perception among state historic preservation office officials is that the time to work on process civil rights projects - such as nominations for sites related to and significant for the LGBTQ+ community-is sparse.

\section{Takeaway message 3. LGBTQ+ organizations are applying for funding and want to landmark significant LGBTQ+ places.}

Moving forward with commemorating historically significant gay places, it is important now more than ever to raise public awareness about the LGBTQ+ community's contributions throughout the history of the United States and also important to draw attention to the struggles LGBTQ+ individuals have endured to advance the fight for equality, civil rights, and acceptance. The preservation of historically significant LGBTQ+ sites endeavors to make the invisible visible so that future generations are able to learn, commemorate, and celebrate LGBTQ+ community and heritage. 


\section{References}

Beckett, L (2016). Orlando nightclub attack is deadliest US mass shooting in modern history. The Guardian, June 12, 2016. https://www.theguardian.com/us-news/2016/jun/12/orlando-nightclubdeadliest-mass-shooting-terrorism

Bitterman A (2020a) Rainbow diaspora: the emerging renaissance of gay neighbourhoods. Town Plann Rev 91(2):99-108

Bitterman A (2021) The rainbow connection: a time-series study of rainbow flag display across nine Toronto neighborhoods. In: Bitterman A, Hess DB (eds) The life and afterlife of gay neighborhoods: renaissance and resurgence. Springer, Dordrecht, Netherlands, pp 117-140

Bitterman A, Hess DB (2016) Gay ghettoes growing gray: transformation of gay urban districts across North America reflects generational change. J Am Cult 39(1):55-63

Bitterman A, Hess DB (2021) Understanding generation gaps in LGBTQ+ communities: perspectives about Gay neighborhoods among heteronormative and homonormative generational Cohorts. In: Bitterman A, Hess DB (eds) The life and afterlife of Gay neighborhoods: renaissance and resurgence. Springer, Dordrecht, Netherlands, pp 309-340

Carter D, Dolkart, AS, Harris G, Shockley J (1999) National historic landmark nomination: Stonewall (Waterford, NY: New York). Office of Parks, Recreation and Historic Preservation. https://www.nps.gov/heritageinitiatives/LGBThistory/stonewall_national_historic_landmark_ nomination.pdf

Civil War Sites Advisory Commission (1993) Civil War sites advisory commission report on the Nation's Civil War Battlefields. National Park Service, Washington, DC

Chibbaro Jr L (2018) LGBT historic site projects continue under Trump. Washington Blade, February 7, 2018. https://www.washingtonblade.com/2018/02/07/lgbt-historic-site-projects-con tinue-trump/

Coffin J (2021) Plateaus and afterglows: theorizing the afterlives of gayborhoods as post-places. In: Bitterman A, Hess DB (eds) The life and afterlife of gay neighborhoods: renaissance and resurgence. Springer, Dordrecht, Netherlands, pp 373-391

Dolkart A, Lustbader K (2020) Co-founders for the NYC LGBT historic sites project. Interview by Camden Miller

Dolkart, AS, Lustbader K, Shockley J, Davis A (2015) NYC LGBT historic sites project. https:// www.nyclgbtsites.org/about/

Duberman MB (2019). Stonewall: the definitive story of the LGBTQ rights uprising that changed America. Plume

Frisch M (2021) A queer reading of the United States census. In: Bitterman A, Hess DB (eds) The life and afterlife of gay neighborhoods: renaissance and resurgence. Springer, Dordrecht, Netherlands, pp 61-85

Gans HJ (1975) Preserving everyone's Noo Yawk. New York Times, January 28, 1975

Garretson JJ. 2018. The path to gay rights: how activism and coming out changed public opinion: NYU Press

Ghaziani A (2021) Why Gayborhoods matter: the street empirics of urban sexualities. In: Bitterman A, Hess DB (eds) The life and afterlife of gay neighborhoods: renaissance and resurgence. Springer, Dordrecht, Netherlands, pp 87-114

Gossett Tanya M, Bryan Mitchell H (2007) Report to congress on the historic preservation of revolutionary war and war of 1812 sites in the United States. National Park Service, Washington, DC

Hanhardt CB (2013). Safe space: gay neighborhood history and the politics of violence. Duke University Press, Durham

Hayden D (1997) The power of place: urban landscapes as public history MIT Press, Cambridge

Hess DB (2019) Effects of gentrification and real-estate market escalation on gay neighbourhoods. Town Plann Rev 90(3):229-237

Hess DB, Bitterman A (2021) Who are the people in your gayborhood? Understanding population change and cultural shifts in LGBTQ+ neighborhoods. In: Bitterman A, Hess DB (eds) The life 
and afterlife of gay neighborhoods: renaissance and resurgence. Springer, Dordrecht, Netherlands, pp 3-39

Kinahan KL, Ruther MH (2020) Uncovering the relationship between historic districts and same-sex households. J Am Plann Assoc, 1-14

LaFrank K (2020). NYS parks \& sites historian at the New York state historic preservation office. Interview by Camden Miller

Mayes TM (2018) Why old places matter: how historic places affect our identity and well-being. Rowman \& Littlefield, Lanham, ML

National Park Service (2008) Civil rights in America: a framework for identifying significant sites. Edited by U.S. Department of the Interior. Washington, DC: National Historic Landmarks Program

National Park Service (2014) Secretary Jewell, Director Jarvis announce \$500,000 in Matching grants to support diversity in National Register of Historic Places

National Park Service (2019a) Administrative history: LGBTQ heritage initiative. Edited by U.S. Department of the Interior

National Park Service (2019b) LGBTQ America: a theme study of Lesbian, Gay, Bisexual, Transgender, and queer history. Edited by U.S. Department of the Interior. Washington, DC: National Park Foundation

National Park Service (2019c) Telling all Americans' stories: introduction. https://www.nps.gov/ subjects/tellingallamericansstories/index.htm

National Park Service (2019d) Telling all Americans'stories: LGBTQ heritage. https://www.nps. gov/subjects/tellingallamericansstories/lgbtqheritage.htm

National Park Service (2019e) Telling all Americans' stories: LGBTQ heritage featured places. https://www.nps.gov/subjects/tellingallamericansstories/lgbtqplaces.htm

National Park Service (2020a) 2020 battlefield preservation planning grant awards. https://www. nps.gov/articles/000/2020-planning-grant-awards.htm

National Park Service (2020b) Underrepresented community grants. https://www.nps.gov/preser vation-grants/community-grants.html

National Park Service (2020c) Underrepresented grants 2014-2019 dataset

National Park Service, Quist, Rainbow Heritage Network (2016) History pin: LGBTQ America. https://www.historypin.org/en/lgbtq-america/geo/37.438179,-96.631589,3/bounds/-21.045 601,-136.002196,70.987613,-57.260982/paging/1

National Park Service Cultural Resources (1990) National register bulletin: how to apply the national register criteria for evaluation. In: Technical information on the national register of historic places: survey, evaluation, registration, and preservation of cultural resources, edited by U.S. Department of the Interior, Washington, DC

National Park Service Cultural Resources (1999) National register bulletin: how to prepare national historic landmark nominations. In: Technical information on the national register of historic places: survey, evaluation, registration, and preservation of cultural resources, edited by U.S. Department of the Interior, Washington, DC

University of New Orleans History Department (2012) Upstairs lounge fire. New orleans historical. https://neworleanshistorical.org/tours/show/39

Newport F (2018) In U.S., estimate of LGBT population rises to 4.5\%. Gallup. https://news.gallup. com/pol1/234863/estimate-lgbt-population-rises.aspx

Rainbow Heritage Network (2015) About the Rainbow Heritage Network. https://rainbowheritage network.org/about/

Sheerin J (2018) Matthew Shepard: the murder that changed America. BBC, October 26, 2018. https://www.bbc.com/news/world-us-canada-45968606

Spring A (2021) Breaking down segregation: shifting geographies of male same-sex households within desegregating cities. In: Bitterman A, Hess DB (eds) The life and afterlife of Gay neighborhoods: renaissance and resurgence. Springer, Dordrecht, Netherlands, pp 43-59

Sprinkle JH Jr (2007) "Of exceptional importance": the origins of the "fifty-year rule" in historic preservation. The Public Historian 29(2):81-103 
U.S. Department of the Interior (1966) National historic preservation act of 1966. In: Public Law 102-575, edited by U.S. Department of the Interior. Washington, DC: National Park Foundation

U.S. Department of the Interior (2014a) Secretary jewell announces new National Park Service theme study to interpret, commemorate sites related to Lesbian, Gay Bisexual, Transgender History. New York, NY

U.S. Department of the Interior (2014b) Secretary jewell, director Jarvis announce $\$ 500,000$ in matching grants to support diversity in national register of historic places

U.S. Department of the Interior (2017a) Interior department announces grants for underrepresented communities through historic preservation fund

U.S. Department of the Interior (2017b). National park service announces $\$ 500,000$ in grants to support diversity in the national register of historic places

U.S. Department of the Interior (2019). National park service announces $\$ 500,000$ in underrepresented community grants

U.S. Office of the Press Secretary (2016) President Obama designates Stonewall National Monument. Washington, DC

Wood B (1999) With heritage so rich. Edited by National trust for historic preservation

Zinn H (2014) A people's history of the United States. Pan Macmillan, London

Camden Miller is a Ph.D. candidate in Urban and Regional Planning at the University at Buffalo, SUNY with a focus on housing, community development, and neighborhood planning. Camden received her Master in Urban Planning with a specialization in Community Development and Neighborhood Planning and an Advanced Graduate Certificate in Historic Preservation from the University at Buffalo in 2016. She is working on projects involving the investigation of housing market dynamics (its limitations and exclusion of under-represented groups) and how we can work towards providing high-quality affordable housing for everyone within the housing market.

\begin{abstract}
Alex Bitterman is Professor of Architecture and Design at SUNY Alfred State. He is an awardwinning educator, culturalist, and author of The College Question: Why College as We Know It Isn't Working for the Millennial Generation. A recognized expert in place branding and neighborhood change, he has recently published several articles and commentary about the experience of LGBTQ+ individuals in urban space. He is an advocate for LGBTQ+ rights and is committed to social justice and professional responsibility. In addition, he is the founding editor of Multi: The Journal of Responsible Architecture and Design (http://www.multi-journal.org, ISSN 1942-3527) a refereed scholarly journal serving a global audience and is the editor and host of the podcast that accompanies this book, The People in Your Gayborhood, available online at http://www.the peopleinyourgayborhood.com.
\end{abstract}

Open Access This chapter is licensed under the terms of the Creative Commons Attribution 4.0 International License (http://creativecommons.org/licenses/by/4.0/), which permits use, sharing, adaptation, distribution and reproduction in any medium or format, as long as you give appropriate credit to the original author(s) and the source, provide a link to the Creative Commons license and indicate if changes were made.

The images or other third party material in this chapter are included in the chapter's Creative Commons license, unless indicated otherwise in a credit line to the material. If material is not included in the chapter's Creative Commons license and your intended use is not permitted by statutory regulation or exceeds the permitted use, you will need to obtain permission directly from the copyright holder.

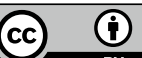

